\title{
CONTRIBUTING FACTORS OF RICKETS AMONG CHILDREN AT HYDERABAD
}

\author{
Rehana Majeed, Yasmeen Memon, Mansoor Khowaja, Farrukh Majeed, \\ Mohammad Usman Ali and Uzma Rajar
}

\begin{abstract}
OBJECTIVE: To determine the factors contributing to nutritional rickets among the children presenting at Isra University Hospital Hyderabad, Sindh - Pakistan.

DESIGN: A case control study.

SETTING: The Pediatrics Department of Isra University Hospital Hyderabad from August 2004 to August 2005.

METHODS: Children less than 5 years of age of both sexes were included in study. Sixty children with rickets and 60 control children matched for age and social characteristics over study period were studied. Diagnosis was made on clinical, radiological and biochemical parameters. A specially designed questionnaire was administered, for patients and mothers of control subjects to assess the role of social, nutritional and other related factors in the pathogenesis of nutritional rickets. Biochemical investigations included estimation of serum calcium, serum phosphorus and alkaline phosphates.

RESULTS: At the time of diagnosis, mean bodyweights of the patients and controls were 9.30 and $10.17 \mathrm{~kg}$ respectively. Mean heights at the time of diagnosis were 60.08 and $62.38 \mathrm{~cm}$ for the patients and the controls respectively. Mean serum calcium and serum phosphate were significantly lower in the patients compared with the controls. Alkaline phosphates were higher among the patients. The weaning diet was started at the age of 6 months only in $30 \%$ of cases of rickets, compared with $52 \%$ of controls who started at the 6 months of age. Only $41 \%$ of mothers of children with rickets had normal nutritional status and $75 \%$ of control mothers had normal nutritional status. Most of the children with rickets $(75 \%)$ were completely wrap during infancy compared to controls; only $20 \%$ wrapped.

CONCLUSION: There are a lot of contributing factors for nutritional rickets. However, several factors seem to make more important contribution. Among these, lack of exposure to sunlight, prolonged breast-feeding without supplementation and inadequate complementary feeding practices are important. Maternal health and education is important as it can influence all of the above factors.
\end{abstract}

KEY WORDS: Nutritional Rickets. Risk Factors. Breast Feeding. Feeding Practices.

\section{INTRODUCTION}

Mineralisation of osteoid tissue of bone is dependent on a suitable supply of minerals, both calcium and phosphate. Failure to provide sufficient mineral results in osteomalacia ${ }^{1}$, which, in growing bone with its attendant growth plates and unfused epiphyses, is manifested as rickets. Although, vitamin D deficiency is not the only cause of rickets (nutritional calcium deficiency has also recently been proposed as an important factor. It has historically been a major cause of morbidity. ${ }^{2}$ Vitamin $D$ is mainly derived from the action of sunlight on 7-dehydrocholesterol in the skin, and vitamin $\mathrm{D}$ deficiency is more likely to occur in individuals with darker skins or in those whose skin is extensively covered. Vitamin $\mathrm{D}$ deficiency in pregnant mothers also limits fetal growth. ${ }^{3}$ In addition, vitamin D may have an important part to play in preventing other dis- eases such as hypertension, various cancers, and type 1 diabetes. ${ }^{5}$ Rickets is a relatively rare condition in Western societies and, when it presents, is often associated with some form of metabolic disturbance of vitamin D metabolism, which may be primary (for example, vitamin D dependent rickets type I, an in born error of metabolism of vitamin D; or vitamin D dependent rickets type 2, end organ resistance to the action of vitamin D) or secondary (for example, associated with liver or kidney disease), or a defect in renal tubular function (for example, hypophosphataemic vitamin D resistance rickets). However, rickets is also prevalent in sunnier climates, ${ }^{6}$ although here it seems that malnutrition may be a contributing factor. ${ }^{7}$ Darker skinned individuals are just as capable as those with lighter skins of synthesizing vitamin $D$, but require greater exposure to ultraviolet light to do so. Other factors, such as nutritional deficiency associated with 
macrobiotic, vegetarian", strict vegan ${ }^{10}$ or "healthy food" milk alternative ${ }^{11}$ diets, and low exposure to sunlight, either by staying indoors or covering the skin are also important. ${ }^{12}$ Breast milk contains little vitamin $D$ and breast fed infants should receive vitamin D supplements. Vitamin D deficiency classically presents with symptoms of bony deformity such as bowed legs, swelling of the wrists, a "rickety rosary", and muscle weakness. If the rickets is severe enough, fractures may ensue ${ }^{13}$ and may simulate child abuse. ${ }^{14}$. However, a significant proportion of these patients have symptoms of hypocalcaemia, which may cause convulsions, stridor, and neuromuscular irritability. ${ }^{15,16} \mathrm{Nu}$ tritional rickets has been seen in developing countries. Following the recognition of principal cause, rickets was largely eradicated in Western world. This study was conducted to determine the role of different possible risk factors causing vitamin $D$ deficiency or nutritional rickets among the children in our part of world.

\section{SUBJECTS AND METHODS}

Sixty children with rickets and 60 control children matched for age and social characteristics were included. Diagnosis was made on clinical, radiological and biochemical parameters. A specially designed questionnaire was administered, to both mothers of patients and mothers of control subjects, to assess the role of social, nutritional and other related factors in the pathogenesis of nutritional rickets. Biochemical investigations included estimation of serum calcium, serum phosphorus and serum alkaline phosphate. Patients with the clinical features of rickets were included. The clinical criteria considered for the diagnosis of rickets were: hypotonia, skeletal deformity, for example bowing of the legs and deformity of the lower end of the long bones, rachitic rosary, delayed closure of the fontanel, delayed walking and delayed dentition. Control group matched for age and social characteristics and who had presented with a non-nutritional illness. Details of the medical history, clinical and laboratory data were recorded, on specially designed forms. The medical history included gestational period, birth weight, type of delivery, number of children in the family, developmental aspects, illnesses and treatment received etc. The social history included parental education, profession and the type of house where the family lived. Special emphasis was given to recording the frequency and duration of exposure of the child to sunlight during early childhood, the dress of the mothers and the usual practice of wrapping the child. The detailed nutritional history of the child included the duration of breast-feeding, age at the introduction of semisolid feeds. We did thorough physical examination, including measurement of weight, height, head circumference and status of the anterior fontanel etc. Signs of clinical rickets were carefully examined and recorded. Diagnosis of rickets was made on clinical signs and was confirmed by radiological and biochemical investigations; serum alkaline phosphates, serum calcium and serum phosphorus were estimated. Patients whose symptoms were suggestive of having non-nutritional rickets like Vitamin D resistance or secondary rickets were not included in the study. Data processing and statistical analysis were performed using software programme SPSS 11.0 on Windows XP.

\section{RESULTS}

60 children with rickets and 60 control children were included in this study. Table I shows the clinical manifestations of rickets. Most common manifestation was widely open anterior fontanel 50(83\%), followed by skeletal deformity $35(58.33 \%)$, rickety rosary $42(70 \%)$, gross motor delay 42(70\%), convulsions 7 (11.66\%) and chest deformity 5(8.33\%). Table II shows the comparison of social factors between control and rickets groups. Most of rickets patients were kept wrapped $45(75 \%)$ compared with control $12(20 \%)$, during their early month of life. Only 15(25\%) rickets patients were exposed to sunlight for at least half an hour of day as compared to controls 38(63.33\%). Only15 (25\%) rickety children lived in open houses (rest of living in flats or covered houses.) 25 controls had also same status of living. Family income of both groups was similar, 26(46\%) having > Rs. 3000 per month. Table III shows nutritional factors of both groups. Among these, 35(58.33\%) rickety children were exclusively on breast feeding, as compared to 20 (33.33\%) of control group. 14(23\%) and 15(25\%) children of rickets and controls respectively were on formula milk. In control group, significantly higher number $52(86.66 \%)$ as compared to rickets started weaning at age of 4-6 months. Table IV shows maternal factors. Nutritional status was normal in 25(41.66\%) mothers of rickets group as compared to control mothers where $45(75 \%)$ had normal nutritional status, which is significant. $52(86 \%)$ mothers in ricket group had more than 2 children under 5 years of age which was significantly higher than control 23(38\%). Mothers using Burqa similar 30(50\%), 31(51.66\%) in each group respectively. Education and consumption of milk was not significantly different. Table $\mathbf{V}$ shows the mean weight $(9.3 \mathrm{~kg})$ and length $(60.08 \mathrm{~cm})$ of the rickets patients at diagnosis. They were not significantly lower than the controls $(10.17 \mathrm{~kg}$ and $65.50 \mathrm{~cm}$, respectively). Head circumference was not significantly different between the two groups. The significant difference between serum calcium, serum phosphate, and alkaline phosphate between control and rickets cases is presented in Table VI. 
TABLE I:

CLINICAL SIGNS OF NUTRITIONAL RICKETS $(n=60)$

\begin{tabular}{|l|c|c|}
\hline \multicolumn{1}{|c|}{ Sign } & Number of cases & $\%$ \\
\hline $\begin{array}{l}\text { Widely open an- } \\
\text { terior fontanel }\end{array}$ & 50 & 83.33 \\
\hline $\begin{array}{l}\text { Gross motor } \\
\text { delay }\end{array}$ & 42 & 70 \\
\hline Rickety rosary & 40 & 66.66 \\
\hline $\begin{array}{l}\text { Skeletal } \\
\text { deformity }\end{array}$ & 35 & 58.33 \\
\hline $\begin{array}{l}\text { Prominent head } \\
\text { bossing }\end{array}$ & 20 & 33.33 \\
\hline $\begin{array}{l}\text { Delayed eruption } \\
\text { of teeth }\end{array}$ & 20 & 33.33 \\
\hline Convulsions & 7 & 8.33 \\
\hline Chest deformity & 5 & 11.66 \\
\hline
\end{tabular}

TABLE II:

SOCIAL FACTORS OF RICKETS

\begin{tabular}{|l|c|c|c|c|}
\hline \multicolumn{1}{|c|}{ Factor } & $\begin{array}{c}\text { Cases } \\
(\mathbf{n}=60)\end{array}$ & $\%$ & $\begin{array}{c}\text { Con- } \\
\text { trols } \\
(\mathbf{n}=60)\end{array}$ & $\%$ \\
\hline $\begin{array}{l}\text { 30 minute ex- } \\
\text { posure to sun }\end{array}$ & 15 & 25 & 38 & 63.33 \\
\hline $\begin{array}{l}\text { Complete } \\
\text { wrapping of } \\
\text { child }\end{array}$ & 45 & 75 & 12 & 20 \\
\hline $\begin{array}{l}\text { Living in open } \\
\text { house }\end{array}$ & 15 & 25 & 38 & 63.33 \\
\hline $\begin{array}{l}\text { Family income } \\
\text { per month } \\
>3000 \text { RS }\end{array}$ & 26 & 43.33 & 25 & 43 \\
\hline
\end{tabular}

TABLE III:

NUTRITIONAL FACTORS

\begin{tabular}{|l|c|c|c|c|}
\hline \multicolumn{1}{|c|}{ Factor } & $\begin{array}{c}\text { Cases } \\
(\mathbf{n = 6 0 )}\end{array}$ & $\%$ & $\begin{array}{c}\text { Con- } \\
\text { trols } \\
(\mathbf{n = 6 0 )}\end{array}$ & $\%$ \\
\hline $\begin{array}{l}\text { Exclusively } \\
\text { breast fed }\end{array}$ & 35 & 58.33 & 20 & 33.33 \\
\hline $\begin{array}{l}\text { Complemen- } \\
\text { tary feeding at } \\
\text { age of 6 months }\end{array}$ & 18 & 30 & 52 & 86.66 \\
\hline $\begin{array}{l}\text { Vitamin D sup- } \\
\text { plement }\end{array}$ & 05 & 8.3 & 32 & 53.3 \\
\hline Formula feed & 14 & 23.33 & 15 & 25 \\
\hline Cows milk feed & 45 & 75 & 21 & 35 \\
\hline
\end{tabular}

TABLE IV:

MATERNAL FACTORS

\begin{tabular}{|l|c|c|c|c|}
\hline \multicolumn{1}{|c|}{ Factor } & $\begin{array}{c}\text { Cases } \\
(\mathbf{n}=\mathbf{6 0})\end{array}$ & $\%$ & $\begin{array}{c}\text { Con- } \\
\text { trols } \\
(\mathbf{n = 6 0 )}\end{array}$ & $\%$ \\
\hline $\begin{array}{l}\text { Normal nutri- } \\
\text { tional status }\end{array}$ & 25 & 41.66 & 45 & 75 \\
\hline $\begin{array}{l}\text { Having>2 chil- } \\
\text { dren under 5 }\end{array}$ & 52 & 86.66 & 23 & 38.33 \\
\hline Using burqa & 30 & 50 & 31 & 51.66 \\
\hline $\begin{array}{l}\text { Education>5 } \\
\text { classes }\end{array}$ & 10 & 16.66 & 18 & 30 \\
\hline $\begin{array}{l}\text { 500ml milk } \\
\text { consumption } \\
\text { per day }\end{array}$ & 8 & 13.33 & 16 & 26.66 \\
\hline
\end{tabular}

TABLE V:

GENERAL FEATURES

\begin{tabular}{|l|c|c|c|c|}
\hline Feature & $\begin{array}{c}\text { Cases } \\
(\mathbf{n = 6 0}) \\
\text { Mean }\end{array}$ & $\begin{array}{c}\text { Con- } \\
\text { trols } \\
(\mathbf{n = 6 0}) \\
\text { Mean }\end{array}$ & $\begin{array}{c}\text { 95\% confi- } \\
\text { dence in- } \\
\text { terval }\end{array}$ & $\begin{array}{c}\text { P- } \\
\text { value }\end{array}$ \\
\hline Age (month) & 12.18 & 11.90 & $10.90-12.89$ & $<.005$ \\
\hline Weight & 9.3 & 10.13 & $8.7-10.60$ & $<.005$ \\
\hline $\begin{array}{l}\text { Occipital } \\
\text { frontal cir- } \\
\text { cumference }\end{array}$ & 45.55 & 45.03 & $45.27-45.82$ & $<.005$ \\
\hline Height & 60.08 & 65.61 & $58.73-66.40$ & $>.053$ \\
\hline
\end{tabular}




\begin{tabular}{|c|c|c|c|c|}
\hline & $\angle A B C$ & $\begin{array}{r}\text { TABL } \\
\text { RATOR }\end{array}$ & $\begin{array}{l}\text { VI: } \\
\text { FINDINGS }\end{array}$ & \\
\hline Test & $\begin{array}{l}\text { Cases } \\
(n=60) \\
\text { Mean }\end{array}$ & $\begin{array}{l}\text { Con- } \\
\text { trols } \\
(n=60) \\
\text { Mean }\end{array}$ & $\begin{array}{l}95 \% \text { confi- } \\
\text { dence inter- } \\
\text { val }\end{array}$ & P-value \\
\hline $\begin{array}{l}\text { Serum } \\
\text { calcium }\end{array}$ & 7.5 & 8.6 & $7.2-8.7$ & $>0.005$ \\
\hline $\begin{array}{l}\text { Serum } \\
\text { phos- } \\
\text { phorus }\end{array}$ & 1.99 & 2.7 & $1.8-2.8$ & $>0.005$ \\
\hline $\begin{array}{l}\text { Serum } \\
\text { alkaline } \\
\text { phos- } \\
\text { phates }\end{array}$ & 976.96 & 178.35 & $156.07-1077.61$ & $>0.007$ \\
\hline
\end{tabular}

\section{DISCUSSION}

Vitamin $D$ deficiency or nutritional rickets in children is almost eliminated in the industrialized countries by prophylactic means. However, it remains major health problem in under developed countries of Asia. ${ }^{16-18} \mathrm{Hu}-$ mans are able to synthesize vitamin $D$ in the skin with the aid of exposure to sunlight. In the abundance of sunlight in our part of world, it is therefore not expected to see large number of children suffering from rickets. It has been clear that some of the factors play more important role for contribution of nutritional rickets. Several studies have assessed vitamin D deficiency rickets in Pakistani children. ${ }^{19-21}$ The prevalence and true incidence in Hyderabad is not known. High incidence of sub clinical rickets (without clinical manifestation) in immigrant's children have been reported in Denmark (46\% in 0-8 years and $81 \%$ in $9-16$ years) ${ }^{22}$ Nutritional rickets is also reported from Tehran $^{23}$ and some other Arab countries. ${ }^{24}$ These countries, however, are economically affluent and have an abundance of sunlight. From the present study, it has become clear that some of the factors play a more critical role than others in causing nutritional rickets. These factors have been quantified. For example, lack of exposure to sunlight due to complete wrapping of the child was found to have an important role. It demonstrates clearly that maternal education, lack of exposure to sunlight due to complete wrapping of the children and a poor weaning diet were more important than the other factors. Most of the rickets patients were breast-fed. However, the value of breast milk as a source of vitamin D is debated. Specker ${ }^{29}$ has documented seasonal variation in vitamin $D$ in exclusively

breast fed infants younger than six months of age. These changes are directly related to ultraviolet light exposure. Milk provides as little as 10 IU of vitamin D/ day in winter and $20 \mathrm{IU} /$ day in the summer. ${ }^{12}$ The lower amount of vitamin $D$ content of breast milk during the winter and early spring seasons, and lesser opportunity of infants to receive sunshine exposure, explains the occurrence of rickets.

Recent editorials in the Journal of Pediatrics have commented that vitamin $\mathrm{D}$ deficiency rickets is reemerging from a once-conquered disease, and that the prescription of regular sunlight exposure is not only difficult to quantify, but also may be in conflict with other health problems such as occurrence of skin cancer. ${ }^{29}$ Recently, there have been many reports on the relation between exposure to ultraviolet $B$ radiation, which produces vitamin $D$ in the skin and skin cancer. Public education projects for skin cancer prevention in children by reducing sunlight exposure have been started in many countries. ${ }^{23}$ Breast-fed infants in Japan take $400 \mathrm{IU}$ of vitamin D per day if they do not receive adequate sunlight exposure. ${ }^{24}$ The results of this present study have brought a few more facts to light. For example, maternal education and health seemed to be an important factor. In contrast, maternal dressing, such as burqa, does not seem to have any role in the etiology of rickets. It is important to note that, compared with the controls, the rickets patients in general demonstrated clinical as well as biochemical features of malnutrition. Weight, height and serum values for calcium and phosphorus were all lower in the rickets patients. This suggests that the rickets patients in general were more malnourished. Maternal education may play an important role. It is expected that an educated mother will have better and improved child-rearing practices. This was reflected in the behavior of our control mothers, who were more aware of the complementary feeding, its quality and for starting to wean. In present study, commonest clinical manifestation was widely open anterior fontanel followed by gross motor delay and rickety rosary. Tahir, et al reported $20 \%$ of motor delay. ${ }^{26}$ Vitamin D deficiency in childhood can cause rickets whose signs and symptoms include bone deformities and fractures, muscle weakness, developmental delays, short stature, failure to thrive, respiratory distress, tetany, and heart failure. ${ }^{27}$ Hypocalcemic fits were present in $11.66 \%$ cases. Hypocalcaemia is more common in initial stages of nutritional rickets, especially during rapid growth. ${ }^{9}$ Hameed, et $\mathrm{al}^{21}$ and Tahir, et $\mathrm{al}^{26}$ have reported $10 \%$ and $20 \%$ children respectively with nonfebrile fits suffering from nutritional rickets. Malnutrition has been reported in literature as a contributing factor for nutritional rickets. A study conducted in slum 
areas of Karachi, 99\% of children with nutritional rickets were malnourished. ${ }^{17}$ Another study from Hazara Division has reported $40 \%$ children under weight according to Gomez classification. ${ }^{26}$

\section{CONCLUSION}

Nutritional rickets is a multifactorial condition. However, several factors seem to make important contributions. Among these, lack of exposure to sunlight, prolonged breast-feeding without supplementation and inadequate weaning practices are important. It is almost certainly the case that the clinically apparent cases of vitamin D deficiency represent the "tip of the iceberg". Unfortunately, this is one iceberg, which, despite global warning and the attendant increase in sunshine, is not diminishing insize. It is suggested that a national campaign to promote awareness of the risks of vitamin D deficiency, particularly among susceptible populations be done to eliminate rickets as a cause of morbidity.

\section{REFERENCES}

1. DeLucia MC, Minick ME, Carpenter TO. Nutritional rickets with normal circulating 25hydroxyvitamin D: a call for reexamining the role of dietary calcium intake in North American infants. J Clin Endocrinol Metab. 2003; 88:3539-45.

2. Mughal Z. Rickets in childhood. Semin Musculoskel Radiol. 2002; 6:183-90.

3. Brunvand L, Quigstad E, Urdal P, Haug E. Vitamin D deficiency and fetal growth. Early Hum Devel. 1996; 45:27-33.

4. Holick MF. Vitamin D: a millennium perspective. J Cell Biochem. 2003; 88:296.

5. Berry JL, Davies M, Mee AP. Vitamin D metabolism, rickets, and osteomalacia. Semin Musculoskel Radiol. 2002; 6:173-82.

6. Hayward I, Stein MT, Gibson MI. Nutritional rickets in San Diego. Am J Dis Child. 1987; 141:1060-2.

7. Salimpour R. Rickets in Tehran. Study of 200 cases. Arch Dis Child. 1975; 50:63-6.

8. Dagnelie PC, Vergote FJ, van Staveren WA, van den Berg $H$, Dingian PG, Hautvast JG. High prevalence of rickets in infants on macrobiotic diets. Am J Clin Nutr. 1990; 51:202-8.

9. Edidin DV, Levitsky LL, Schey W, Dumbovic N, Campos A. Resurgence of nutritional rickets associated with breast-feeding and special dietary practices. Pediatrics 1980; 65:232-5.

10. James JA, Clark C, Ward PS. Screening Rastafarian children for nutritional rickets. BMJ. 1985; 290:899-900.
11. Carvalho NF, Kenney RD, Carrington PH, Hall DE. Severe nutritional deficiencies in toddlers resulting from health food milk alternatives. Pediatrics. 2001;107:E46.

12. Abdullah MA, Salhi HS, Bakry LA, Okamoto E, Abomelha AM, Stevens B, et al. Adolescent rickets in Saudi Arabia: a rich and sunny country. J Pediatr Endocrinol Metab. 2002; 15:1017-25.

13. Al-Jurayyan NA, El-Desouki ME, Al-Herbish AS, Al-Mazyad AS, Al-Qhtani MM. Nutritional rickets and osteomalacia in school children and adolescents. Saudi Med J. 2002; 23:182-5.

14. Paterson CR. Vitamin D deficiency rickets simulating child abuse. J Pediatr Orthop.1981; 1:423-5.

15. Narchi H, El Jamil M, Kulaylat N. Symptomatic rickets in adolescence. Arch Dis Child. 2001; 84:501-3.

16. Bonnici F. Functional hypoparathyroidism in infantile hypocalcaemia stage I vitamin D deficiency rickets. S Afr Med J.1978; 54: 611-12.

17. Jamal A, Khanani AR, Billo G, Asger A, Jafri Z. Rickets in a slum of Karachi. Pak J Med Sci. 1996; 12(3) 247-50.

18. Iqbal SJ, Garrick DP, Howl A. Evidence of continuing deprivational vitamin $D$ deficiency in Asians in the UK. J Hum Nutr Diet.1994a; 7: 4752.

19. Iqbal SJ, Khaddam I, Wassif W, Nicol F, Walls J. Continually clinical severe Vit $D$ deficiency in Asian in the UK(Leicester) post grad.1994b.Med J.70;708-

20. Karrar ZA. Vit D deficiency rickets in developing countries. Ann Trop Paediatr. 1998;18:s89-s92.

21. Hameed A, Ahmed S, Rehman S, Urakzai AA, Gandapoor AJ. A study of rickets morbidity and etiology of a low profile disorder. J Post Med Inst. 1998; 12(2): 14-12.

22. Gerup H, Rytter L, Mortenson L Nathan E. Vitamin $D$ deficiency among immigrant children in Denmark. Eur J Pediatr. 2004; 163:272-73.

23. Mahmoud R. Rickets in breast-fed infants below six months of age without Vit D supplementation in Tehran

24. Lubani MM, Al-Shab TS, Al-Saleh QA, et al. Vitamin D deficiency rickets in Kuwait: The prevalence of preventable disease. Ann Trop Paediatr. 1989;3:134-9.

25. Buller DB, Borland R. Public education in skin cancer prevention: childcare, school, and collegebased. Clin Derm. 1998:16: 447-59.

26. Tahir SS, Manzoor IR. Presentation and predisposing factors of nutritional rickets in children of Hazara division. J Ayub Med Coll Abbottabad 
2005; 17(3).

27. Garabédian, Mand H., Ben-Mekhbi. Rickets and vitamin D deficiency. In Vitamin D: Physiology, Molecular Biology, and Clinical Applications ed. M. Holick. Humana Press: Totawa, NJ, 1999, 27386.

28. Ladhani S, Srinivasan I, Buchanan C, Allgrove J.
Presentation of Vit D deficiency. Arch Dis Childhood. 2004; 89:781-84.

29. Specker BL, Valanis B, Hertzberg V, Edwards N, Tsnag RC. The sunshine exposure and serum 25hydroxyvitamin $D$ concentration in exclusively breast-fed infants. Pediatr.1985; 107:372-6.

AUTHOR AFFILIATION:
Dr. Rehana Majeed (Corresponding Author)
Assistant Professor, Department of Pediatrics
Isra University Hyderabad, Sindh - Pakistan.
Tel: 022-2030161-70
E-mail: drrehanamajeed@yahoo.com
Dr. Yasmeen Memon
Department of Pediatrics
Liaquat University Hospital
Hyderabad, Sindh - Pakistan.
Dr. Mansoor Khowaja
Department of Community Medicine
Isra University Hyderabad, Sindh - Pakistan.

Dr. Farrukh Majeed
Dow University of Health Sciences
Karachi, Sindh - Pakistan.
Dr. Mohammad Usman Ali
Dow University of Health Sciences
Karachi, Sindh - Pakistan.
Dr. Uzma Rajar
Isra University Hyderabad, Sindh - Pakistan.

